\title{
Legal Aspects of Regional Government Strategies in Overcoming Unemployment, Problems and Solutions
}

\author{
Titik Budiyanti ${ }^{1}$
}

\begin{abstract}
The problems discussed in this study are "the legal aspects of local government strategies in overcoming unemployment, problems and solutions in Demak Regency". In order to discuss this problem, the approach method used is a normative juridical approach, which examines the law that is conceptualized as a norm or rule that applies in society. Sources of data in this study are secondary data sources obtained from primary, secondary and tertiary legal materials.

From the results of the research and discussion, it was concluded that: the legal aspects of the regional government strategy in tackling unemployment in Demak Regency by establishing policies of the Demak Regency Government in attracting investors/ investors, developing employment opportunities, implementing rural productive labor intensive, implementing labor placements, carry out job training and local government policies in collaboration with companies and nongovernmental organizations. Meanwhile, the problems faced by the Regional Government in Tackling Unemployment in Demak Regency are (1) high unemployment. The solution is to implement an employment opportunity expansion program, the implementation of rural productive labor-intensive activities, training and placement of workers (AKL, AKAD / transmigration and AKAN);
\end{abstract}

Keywords : Unemployment; Regional government; Policy; work training

\section{Introduction}

In the era of economic globalization and trade, it has spurred changes in the economic and industrial structure which will automatically affect the structure of the need for labor, both in type and qualification, which tend to be increasingly competent in order to be able to compete in national, regional and international markets. ${ }^{2}$

National development is carried out in the framework of developing the Indonesian people as a whole and the development of Indonesian society as a whole to create a society that is prosperous, just, prosperous, evenly distributed, both materially and spiritually based on Pancasila and the 1945 Constitution of the Republic of Indonesia.

In implementing national development, the workforce has a very important role and position as actors and objectives of development. In accordance with the role and position of the workforce, it is necessary to develop manpower to

\footnotetext{
${ }^{1}$ Government employees

2Dirjen Lattas Depnakertrans RI, 2008, Petunjuk Pelaksanaan Dana Tugas Pembantuan Program PKPTK tahun 2008, Jakarta, p. 1.
} 
improve the quality of the workforce and its participation in development and to increase the protection of workers and their families in accordance with human dignity and dignity. ${ }^{3}$

The State of the Republic of Indonesia as "Welfare - state" is obliged to carry out public welfare, namely to create social justice for all Indonesian people, ${ }^{4}$ as stated in the Preamble to the fourth paragraph of the 1945 Constitution of the Republic of Indonesia, as follows: "Then rather than that to form an Indonesian state government that protects the entire Indonesian nation and all the blood of Indonesia and to promote public welfare, educate the nation's life and participate in implementing world order based on independence, eternal peace and social justice....". 5

The aforementioned statement means that the Indonesian state has a function which is at the same time an obligation to eradicate poverty and tackle unemployment.

Based on Article 27 paragraph (2) of the 1945 Constitution of the Republic of Indonesia, it states "Every citizen has the right to work and a decent living for humanity", and Article 28 D paragraph (2) states "everyone has the right to work. as well as getting fair and proper remuneration and treatment in a working relationship".

"Provides an understanding that the government is obliged to eradicate unemployment and must endeavor so that every citizen can get a job with a decent wage for life". ${ }^{6}$ For this reason, every citizen (job seeker, worker) has equal rights and opportunities without discrimination to obtain decent work and income, both at home and abroad in accordance with their expertise, skills, talents, interests and abilities.

Classically, employment in the country of Indonesia still revolves around limited job creation, relatively high growth in the workforce, coupled with the relatively low levels of education and skills of the workforce, which results in the increasing number of unemployed.

The manpower issue is a very crucial and fundamental problem, especially concerning the increasing number of unemployed. Based on data from BPS in 2006 the unemployment rate reached 10.95 million people. ${ }^{7}$ Taking into account the large number of unemployed people is a challenge for the government to seriously tackle labor issues. Efforts to reduce the unemployment problem are not only the responsibility of the government, but all components of the nation must take part in overcoming it. The number of unemployed, which is increasing from year to year, is largely due to the low levels of education and skills of the Indonesian workforce.

\footnotetext{
${ }^{3}$ B. Siswanto Sastrohadiwiryo, 2003, Manajemen Tenaga Kerja Indonesia (Pendekatan Administratif dan Operasional, Bumi Aksara, Jakarta, p. 3.

${ }^{4}$ Ronny Hanitijo Soemitro, 1989, Perspektif Sosial dalam Pemahaman Masalah-masalah Hukum, Agung, Semarang, p. 64.

${ }^{5}$ Kawan Pustaka editorial team, 2004, Undang-Undang Dasar 1945 \& Perubahannya dan Susunan Kabinet lengkap, Jakarta, p. 2.

${ }^{6}$ Ronny Hanitijo Soemitro, loc. cit.

${ }^{7}$ Dirjen Lattas Depnakertrans RI, 2008, loc. cit
} 
Demak Regency based on Susenas in 2006, the total working age population (15 years and over) was recorded at 728,766 people. The number of labor force was 549,666 people, who worked as many as 469,854 people, so there was open unemployment in 2006 as many as 61,960 people, besides the number of half unemployed was also recorded as 17,852 people. Thus the Labor Force Participation Rate (TPAK) is 75.42\%. and the Open Unemployment Rate (TPT) of $11.27 \% .^{8}$ When viewed from the quality of the workforce as measured by the level of education, most of them are still relatively low, this is reflected in the following percentages: elementary school graduates below 60.84\%, junior high school degrees equivalent to $20.73 \%$, high school equivalent $12.29 \%$, and universities. High $6.14 \%$. Meanwhile, job seekers looking for work were seen at $18.33 \%$ with elementary education and below, 19.29\% junior high school, 50.39\% senior high school and $11.99 \%$ tertiary education. ${ }^{9}$

It often happens that the available job opportunities cannot be filled, because the skills and requirements of the workforce are not suitable. One of the contributing factors, among others, is that there is still a gap between the world of education (training) and the world of work in the sense that there is no match between the provision of knowledge and skills obtained from training with the skills needed in accordance with the job market (potential users of labor / companies). The need for skilled, disciplined and productive manpower is a reasonable guide in tune with technological developments and development activities

To increase the knowledge and quality of skills of job seekers, workers and workers as well as the placement of workers is an obligation, responsibility and implementation carried out by the local government and the people of Indonesia.

Based on Law Number 13 of 2003 concerning Manpower. Manpower development is carried out in the framework of developing Indonesian people as a whole, in order to create a prosperous, just, prosperous and equitable Indonesian human being and society both materially and spiritually. ${ }^{10}$ Also manpower development is carried out in an integrated manner in the form of mutually supportive cooperation for the development of human resources, increasing the productivity and competitiveness of Indonesian workers, efforts to expand job opportunities, service employment placement and fostering industrial relations.

With the promulgation of Law Number 32 of 2004 concerning Regional Government, in general governance in the Indonesian state there have been very large changes, especially changes in the administration of government in the regions, and have given regional authority, regional governments carry out the broadest possible autonomy to regulate and manage the government and are supported by the provision of financial balance funds which contain the consequences of changes in the basic governance system at the central, provincial and district / city levels, as regulated in Article 18 paragraph (2) of the 1945

\footnotetext{
8Bappeda and BPS for Demak Regency, 2007, Statistik Sosial dan Kependudukan Kabupaten Demak, Hasil Susenas, Demak, p. 15-16.

${ }^{9}$ Manpower and Transmigration Office of Demak Regency, LAKIP 2007, p. 6.

${ }^{10}$ Bureau of Law and Organization, Ministry of Manpower and Transmigration of the Republic of Indonesia, 2003, , Undang-undang nomor 13 tahun 2003 tentang Ketenagakerjaan,, Jakarta, p. 68.
} 
Constitution of the Republic of Indonesia which states " Provincial, regency and city governments regulate and administer government affairs themselves according to the principles of autonomy and assistance tasks ",this is often known as Regional Autonomy.

Law Number 32 of 2004 in its explanation that the regional government has the authority to regulate and manage government affairs and the interests of the people in the region according to their own initiatives based on the aspirations of the community, based on the principles of autonomy and assistance tasks, directed to accelerate the realization of community welfare through improvement, service, empowerment and community participation, as well as enhancing regional competitiveness.

The administration of governmental affairs which falls under the authority of regional government consists of mandatory and optional affairs. Meanwhile, Article 14 paragraph (1) of Law Number 32 Year 2004 which states that "Mandatory affairs which become the authority of regional governments for regencies / cities are district / city scale affairs" includes one of them: letter $h$ is "manpower sector services".

One of the regional governments in the regional autonomy era, as it is today, plays a bigger role in the implementation of manpower policies. This is because the manpower sector in Law Number 32 Year 2004 is a mandatory affair held by regional governments which must be within their authority in the regions related to basic services, such as basic education, health, labor, and so on. And the development of special manpower to tackle unemployment is a priority of government programs at both the central and regional levels.

\section{Research methods}

To achieve the desired results, the research method uses a normative juridical approach, namely examining the law that is conceptualized as norms or rules that apply in society and become a reference for everyone's behavior. The type of data required is qualitative descriptive research, both taken from primary and secondary data and examining written or oral laws and real behavior related to unemployment and legal aspects of local government strategies in overcoming unemployment. While the data collection technique is by directly examining the main informant who has been determined using non-random sampling technique by purposive sampling or sampling is done by taking subjects based on certain objectives then cross-checking with supporting informants. The data collection method uses the method of observation, interviews, literature study and documentation which are then discussed and analyzed by qualitative analysis with descriptive data presentation (explanation and description).

\section{Results and Discussion}

Manpower development has many dimensions and linkages between development sectorsone with another sector. This linkage is not only for the interests of the workforce during, before and after the employment period but also between the business world, employers, government, and society as a source of 
labor. And in pelucidation of Article 3 of Law Number 13 Year 2003 states that the principles of manpower development are basically in accordance with the principles of national development, particularly the principles of Pancasila democracy and the principles of fairness and equality. Manpower development has links with various parties, namely the government, employers and workers / laborers. Therefore, manpower development is carried out in an integrated manner in the form of mutually supportive / beneficial cooperation. ${ }^{11}$

Currently, with the high level of open unemployment and the low quality of the workforce in terms of education, expertise, skills and skills to fill existing job vacancies. Whereas in Demak Regency in accordance with the mandate of the 1945 Indonesian Constitution Article 27 paragraph (2) and Article 28 D paragraph (2), the high open unemployment rate and low quality of workforce is the responsibility of the Demak Regency Government, the private sector and the community of Demak Regency. to be able to tackle the unemployment.

Law as a tool for overcoming unemployment is based on existing laws and regulations, among others: Law Number 13 of 2003, Law Number 39 of 2004, Government Regulation Number 31 of 2006, Laws and Government Regulations relating to The annual State Revenue and Expenditure Budget (APBN) as well as its implementing regulations and the Demak Regency Regional Regulations which each year concerning the Demak Regency Regional Revenue and Expenditure Budget and the Demak Regent Regulation concerning the Elaboration of the District Regional Revenue and Expenditure Budget. Demak as the implementing regulations.

Related to the problem of unemployment, it is necessary to have employment as a place where they are looking for work in order to get work opportunities. Job opportunities available in Demak Regency are very limited, because Demak Regency is an agricultural area, not an industrial area. Whereas job seekers are generally less interested in working in the agricultural sector, they are more interested in the financial, industrial and trade sectors, while job vacancies in these sectors are very small.

The legal aspects of the Regional Government's strategy in tackling unemployment in Demak Regency, the Demak Regency Government takes steps and policies that are outlined in formal juridical form (laws and regulations), namely Regional Regulation Number 7 of 2006 concerning the Medium Term Development Plan (RPJM) of Demak Regency 2006-2011, which is implemented by Regional Regulation Number 5 of 2007 concerning the Determination of the 2007 APBD, Regional Regulation Number 1 of 2008 concerning Stipulation of the 2008 APBD, Regulation of the Regent of Demak Number 6 of 2007 concerning the Elaboration of the 2007 APBD, Regulation of the Regent of Demak Number 72007 regarding the 2007 APBD Implementation Guidelines, Demak Regent Regulation Number 1 of 2008 concerning the Elaboration of the 2008 APBD,Demak Regent Regulation Number 2 of 2008 concerning Guidelines for Implementation of the 2008 Regional Budget which includes programs and activities, by implementing the following strategies and policies:

${ }^{11}$ Bureau of Law and Organization of the Ministry of Manpower and Transmigration of the Republic of Indonesia, Op. cit, h. 71. 
1. Demak Regency Government Policy in attracting Investors / Investors, by trimming the bureaucracy, licensing regulations and procedures as well as developing the capacity of the implementing public institutions, through onestop licensing services (One Stop Services); improving the quality of investment services in a consistent and sustainable manner which is carried out appropriately, quickly, cheaply, openly, simply, easily, non-discriminatively and in a way that is not complicated and provides investor information; holding business meetings either from Demak entrepreneurs or from outside Demak; participating in investment promotion exhibitions at both national and regional levels.

2. Policy on Developing Job Opportunities

One of the major problems faced in Demak Regency in the field of manpower is limited employment opportunities and the increasing number of unemployed and underemployed workers with low levels of skills and education. With the expansion of job opportunities, the legal aspects of the local government strategy in tackling unemployment in Demak Regency, to open / create job opportunities for the unemployed with activities, which include:

a. New Entrepreneurship with the application of appropriate technology

b. New Entrepreneurship with the application of appropriate technology with assistance / empowerment using local materials.

c. Independent Workforce Development includes TKMT, TKPMP, TKS.

3. Policy on Implementing Rural Productive Labor Intensive

Labor intensive is carried out within a certain period of time or during the low / low season in the form of work that can provide direct income to unemployed and underemployed workers and is beneficial for the improvement of the community's economy; absorb a lot of workforce, both adult men and women who are able to carry out the work of building facilities and infrastructure that support the community's economy with simple tools; has a positive impact on the empowerment of the workforce, community economic institutions, increases the welfare and income of workers and benefits workers and society.

4. Policy on Implementing Manpower Placement

Domestic placement of workers is the activity of filling job vacancies by job seekers within the territory of the Republic of Indonesia, either directly or through a workforce placement service provider.

Placement of TKI is a service activity to bring together TKI according to their talents, interests and abilities with employers abroad which includes the entire recruitment process, managing documents, education and training, holding, preparing for departure, departure to the destination country and return from the destination country. Improve coordination, guidance and supervision of PPTKIS in the placement of Indonesian migrant workers abroad in order to reduce the presence of illegal TKI. Increasing the competence of prospective migrant workers through provision, education and skills training that are suitable for the work and language of the destination country so that they are able to compete with other countries and are skilled in labor.

5. Policy on Implementing Job Training 
Job training is an entire activity to provide, obtain, improve and develop work competence, productivity, discipline, attitudes and work ethic at a certain skill level and expertise in accordance with the level and qualification of a position or job. Therefore, job training is one way to improve the quality and develop the workforce's career as wellto provide a qualified workforce to fill available job vacancies

The Demak Regency Government in establishing / opening BLK which leads to technopact to train and provide skills in accordance with existing job vacancies at home and abroad that are insightful towards high-tech industries / companies.

6. Local government policies cooperate with companies and non-governmental organizations, especially LPKS

Cooperation between the local government and companies to tackle unemployment through an apprenticeship system, and the Demak Regency Government in collaboration with LPKS through three in one training activities (Training, Certification and Placement) and training program subsidies.

The current Demak Regency Government is still faced with problems in overcoming unemployment in Demak Regency and solutions for solving legal aspects of local government strategies to tackle unemployment in Demak Regency, by implementing programs and activities at the Manpower and Transmigration Office with statutory regulations, namely Regional Regulation Number 7 of 2006 concerning RPJM Demak Regency in 2006-2011, which was implemented by Regional Regulation Number 5 of 2007 concerning the Stipulation of the 2007 APBD, Regional Regulation Number 1 of 2008 concerning Stipulation of the 2008 APBD, Regulation of the Regent of Demak Number 6 of 2007 concerning the Elaboration of the 2007 APBD, Regulations of the Regent of Demak Number 7 of 2007 concerning Guidelines for the Implementation of the 2007 APBD, Regulation of the Regent of Demak Number 1 of 2008 concerning the Elaboration of the 2008 APBD,Demak Regent Regulation Number 2 of 2008 concerning Guidelines for the Implementation of the 2008 Regional Budget for the implementation of unemployment reduction in Demak Regency.

Problems / problems faced by the Demak Regency Government, namely:

1. High Unemployment Rate

The labor force participation rate (TPAK) in 2006 was recorded at 75.42 percent, the open unemployment rate (TPT) in Demak Regency in 2006 was recorded at 11.27 percent. In fact, the reduction of unemployment in Demak Regency is still not resolved, even increasing from year to year, the open unemployment rate continues to increase by an average of $2.17 \%$, so that there were open unemployment in 2006 as many as 61,960 people, and the number of underemployed people as many as 17,852 people.

Troubleshooting solutions, programs and activities,among others: ${ }^{12}$

a. Employment Opportunity Expansion Program:

1) Implementation of rural productive labor-intensive;

\footnotetext{
12 Results of an interview with the Head of the Manpower and Transmigration Office of Demak Regency on 11 August 2008.
} 
2) Transmigration placements;

3) Apprenticeship recruitment to Japan and Japanese language training.

b. Workforce Placement Program

Manpower placement is a process of service to job seekers to get a job and employers in filling job vacancies according to their talents, interests and abilities through the placement of AKL, AKAD and AKAN.

c. Workforce Productivity and Quality Improvement Program;

Increasing the quality and productivity of labor in the regions is directed at improving the quality of human resources through increasing skills, expertise and productivity.

2. Limited employment opportunities / low job opportunities

Problematics which is faced with limited employment opportunities, among others:

a. ineffective labor market and job market information;

b. In conducting the recruitment of prospective Indonesian migrant workers abroad, there are still many fake but original TKI identity documents;

c. the development of independent workers (TKPMP, TKMT, TKS) generally lacks entrepreneurial spirit.

Sulosi solution to problem by implementing programs and activities, among others:

Employment Opportunity Expansion Program, that is:

a. Implementation of rural productive labor-intensive;

b. PPTKIS branch development;

c. Development of job seekers (AK services);

d. Development of the domestic labor market.

3. The low quality and skills of the workforce

When viewed from the quality of the workforce as measured by the level of education, most of them are still relatively low, and job seekers who are looking for work are $18.33 \%$ with elementary education and below, junior high school education: $19.29 \%$, high school by $50.39 \%$ and tertiary education $11,99 \% .^{13}$

Problematics with the low quality and skills of the workforce in Demak Regency as follows:

a. the low level of quality and skills of the workforce in Demak Regency and the lack of standardization and competency certification.

b. The existence of training and productivity institutes (vocational training centers) as a way of developing the quality and productivity of the workforce does not yet have adequate equipment

Solution solution in overcoming unemployment, among others: ${ }^{14}$

Program for improving the quality and productivity of the workforce, that is:

a. Implementation of Work Training Education

Job training education is carried out to increase the skills and skills of

13 Results of an interview with the Head of the Manpower and Transmigration Office of Demak Regency on 11 August 2008.

14 ibid 
job seekers to be trained in various vocational fields. The types of training include:

1) Catering Work Training Education (PLK)

2) PLK Sewing

3) PLK Motorbike Mechanic

4) PLK Las Karbit / Electric

5) PLK for Face / Hair Makeup

6) PLK Bride Carrying Tray

7) PLK Electronics.

8) PLK Embroidery.

b. Procurement of Training Facilities and Infrastructure / BLK.

The Demak Regency Government in developing manpower to tackle unemployment can focus it in the coming years, for activities:

1. Expanding job opportunities through the development of regional potential, both in the formal and informal sectors;

2. Give top priority to training programs that empower job seekers (unemployed) and low productivity workers in the context of tackling unemployment;

3. Increasing the quality and productivity of the workforce through the use of competency-based training resources and community-based training;

4. Implementing policies and job training programs for job seekers (job seekers) by training institutions managed by local governments in improving the quality, relevance and competence of workforce in accordance with the needs of the job market;

5. Implementing the Three In One (Training, Certification and Placement) program, which is the link between training, certification and placement;

6. Maintain employment in the formal sector and industrial sector and prevent widespread layoffs (PHK);

7. Promote the National Movement for Combating Unemployment.

8. Improving the human resource development system through links and matches between general education, professions and competency-based job training;

\section{Closing}

\subsection{Conclusion}

From all the descriptions as mentioned in the previous discussion, in the end the authors can draw the following conclusions:

1. Legal Aspects of Regional Government Strategies in Tackling Unemployment in Demak Regency are Demak Regency Government Policies in attracting investors / investors, by cutting bureaucracy, and licensing procedures, through one-stop permit services which are implemented quickly, cheaply, easily and without complicated winding. The policy to develop the expansion of job opportunities, the problems it faces are limited employment opportunities and the increasing number of job seekers / unemployed, so to create job opportunities, includes new entrepreneurs by implementing TTG 
and mentoring / empowering, fostering independent workers. The policy of implementing labor-intensive rural productive, within a certain period can absorb a lot of labor and provide direct income to the unemployed. Domestic and foreign workforce placement policies. Job training education policy to improve the skills and skills of job seekers to be trained in various vocations. Local government policies work with companies and NGOs, especially LPKS. Local governments collaborate with companies through job apprenticeships, local governments collaborate with LPKS through subsidized programs and three in one training.

2. Problems and Solutions Legal Aspects of Regional Government Strategies in Tackling Unemployment in Demak Regency: High unemployment rate, with. TPT is recorded at 11.27 percent, there are 61,960 open unemployment people, and 17,852 underemployed people, the solution is the job opportunity expansion program to create job opportunities for unemployed people through PKP, Transmigration Placement, apprenticeship to Japan. Workforce placement program through the placement of AKL, AKAD and AKAN. Limited employment opportunities / Low employment opportunities, the industrial sector only absorbs $27.09 \%$ of the workforce, 469,854 people working / working opportunities, when compared to the total population of $1,043,111$ people, only $45.04 \%$, and compared to the working age population of 728,766 people around $64.47 \%$, so job opportunities are low, the solution is PKP Activities, PPTKIS Branch Development, AK Services, Development of the domestic labor market. The low quality and skills of the workforce, the quality of the workforce as measured by the low level of education, can be seen: elementary school graduates below 60.84\%, junior high school equivalent $20.73 \%$, and the lack of training facilities and infrastructure / BLK, the solution is a quality and productivity improvement program workforce to improve the quality of human resources through tailoring, catering, mechanics and others, the provision of training facilities and infrastructure / BLK.

\subsection{Suggestion}

From the results of the research, the discussion comes to conclusions about the Legal Aspects of Regional Government Strategies in Tackling Unemployment in Demak Regency, the author can provide suggestions:

1. Make a Demak Regent Regulation to tackle unemployment and poverty in Demak Regency.

2. Local governments cooperate with companies, private companies and NGOs, especially LPKS to hold apprenticeships, a three in one program (training, certification and placement) of workers both at home and abroad to tackle unemployment.

3. To carry out a job fair, which is an event for direct meetings between job seekers and employers (users) who need workers, in order to facilitate the placement process for both domestic and overseas placements. 


\section{Bibliography}

[1] Dirjen Lattas Depnakertrans RI, 2008, Petunjuk Pelaksanaan Dana Tugas Pembantuan Program PKPTK tahun 2008, Jakarta.

[2] Siswanto Sastrohadiwiryo, 2003, Manajemen Tenaga Kerja Indonesia Pendekatan Administratif dan Operasional, Bumi Aksara, Jakarta.

[3] Ronny Hanitijo Soemitro, 1989, Perspektif Sosial dalam Pemahaman Masalahmasalah Hukum, Agung, Semarang.

[4] Kawan Pustaka editorial team, 2004, Undang-Undang Dasar 1945 \& Perubahannya dan Susunan Kabinet lengkap, Jakarta.

[5] Bappeda and BPS for Demak Regency, Statistik Sosial dan Kependudukan Kabupaten Demak, Hasil Susenas, Demak.

[6] Bureau of Law and Organization, Ministry of Manpower and Transmigration of the Republic of Indonesia, 2003, Undang-undang nomor 13 tahun 2003 tentang Ketenagakerjaan, Jakarta 